\title{
ASSESSING THE IMPACT OF BLOCKCHAIN TECHNOLOGIES ON THE NATIONAL ECONOMY: METHODOLOGICAL APPROACHES AND THEIR TESTING
}

\author{
RASHITOVICH SAFIULLIN Marat ${ }^{1,2}$, \\ TIMERKHANOVICH BURGANOV Rafis ${ }^{3}$, \\ ALEKSEEVICH ELSHIN Leonid ${ }^{1,2,4}$
}

\author{
${ }^{1}$ Kazan Federal University (RUSSIA) \\ ${ }^{2}$ Advanced Economic Research Centre at the Academy of Sciences of the Republic of Tatarstan (RUSSIA) \\ ${ }^{3}$ Kazan State Universities of Architecture and Civil Engineering (RUSSIA) \\ ${ }^{4}$ Kazan National University of Science and Technology (RUSSIA) \\ Email: Leonid.Elshin@tatar.ru
}

\begin{abstract}
Despite the very high interest from international and national financial institutions, and also enterprises from the real sector of the economy demonstrated in the distributed data storage technology, studies on the problems of assessing the use of the blockchain platform potential in the socioeconomic environment, and their theoretical understanding can be met vary rarely. As a rule, existing works reveal either the technical side of the study object or the regulatory or legal aspects of the applicability of blockchain technologies in the national economy. In this regard, this work attempts to overcome this conditional vacuum of understanding in order to make up for conditions with questions revealing other aspects of the research subject, for example, such as the economic and social effects of introducing blockchain technologies into the activities of business entities. A formalized assessment and scenario modeling of the dynamics of GDP growth in the new institutional business environment is carried out on the basis of the emerging effects assessment caused by the integration of distributed data storage technologies into the system of business operations.
\end{abstract}

Keywords: scenario model, economic growth, blockchain, economy's financial sector, GDP, process management, credit risks

We would like to thank you for the help in the arrangement of the article to the members of the scientific project sponsored by the RFBR No. 18-010-00536

JEL: E40

UDC: 005.591.6:330.34

COBISS.SR-ID 28644873

\section{Introduction}

Similar to how the digitalization of the socioeconomic environment destroys traditional areas of business (for example, digital channels replaced analogue ones), blockchain technologies can significantly transform existing business processes, including in the financial sector, thereby continuing to develop the FinTech paradigm. In modern economic conditions, the financial market integrated into the global economy is of fundamental importance for the 
development of the national economic system. The financial market generates hundreds of billions of roubles daily in all kinds of transactions and payments. The volume of electronic payments per year in Russia reaches the level of 1566 trillion roubles (according to data for 2019 [1]).

Realizing the significance and function of blockchain, it is worth mentioning that in spite of the contradictory strategies and opinions of specialists about the practicability and likelihood of applying blockchain technologies in the economic turnover of the economy, individual states are progressing and extending alongside the blockchain evolution route. As a clear instance, it can be mentioned the PRC, where from May 2020 on, the national cryptocurrency of China's Central Bank (DCEP) has been implemented into circulation [4].

From 2020 on, Chinese banks will utilize distributed ledger technology to register accounts, get payments as well as additional goals [5].

Generally speaking, depending on the policies and requirements established forth above, it is worthwhile to mention that blockchain technologies hold a doubly high potential level to optimize the functioning of the economy through decreasing transaction expenses related with:

- Data storage and accounting;

- Look up information regarding counterparties;

- Synchronization of heterogeneous information resources;

- Shift to business patterns with the least mediation level;

- Decrease of financial risks losses stemmed from the usage of incorrect data;

- Automation of business processes on the basis of using smart contracts;

- Shift to a decentralized plan to store and process data;

- A reduction in financial crime level as a consequence of the invariance of data on performed transactions;

- Decrease of time to process databases including actively evolving information concerning assets (transactions time, their owners, value)

It is important to emphasize that methodologically, the study relies on an analysis of the growth in the efficiency of the financial sector of the economy under the influence of the penetration of blockchain technologies through the prism of accounting and evaluating the improvement and optimization of its operational processes. This aspect is highlighted due to the fact that, in our opinion, the study of the blockchain technologies influence on the financial environment and the national economic system as a whole can be built on the basis of two main hypotheses. One of them is based on the hypothesis that distributed data storage technologies create effects that are generated as a result of lower transaction costs for financial transactions. This effect is caused by the potential to reduce intermediary links in ongoing transactions that are being formed as part of the use of peer-to-peer blockchain systems (PPBS).

The second hypothesis determines the growth of the functioning efficiency of the financial sector of the economy due to the optimization of operational processes in credit organizations, which forms the basis for reducing (minimizing) credit and operational risks.

\section{Methods}

At the first stage, scenario analysis of the impact of distributed data storage technologies on the effect of the GDP growth dynamics as a consequence of the transition of financial transactions to the blockchain environment was carried out, thereby forming a new type of financial relationship based on the use of crypto transactions. 
Further, the scenarios of "blockchain transformation" of the economy and the transition of the financial transaction market to the crypto-blockchain environment were arranged so as to develop prognostic evaluations of the crypto transactions effect on the parameters and stability of GDP improvement (Table 1).

Table 1. Scenario examination of commission earnings adjustment to credit organizations as a consequence of the financial system transition to crypto transactions (compiled Given the Russian Federation Central Bank [1] Sensitivity investigation of the decline in commission revenue of credit institutions as a consequence of a reduction in the "Cash Transfer" sign through:

\begin{tabular}{|c|c|c|c|c|c|c|c|c|c|c|c|c|c|c|c|}
\hline \multirow{3}{*}{\multicolumn{2}{|c|}{$\begin{array}{c} \\
\text { Entire money } \\
\text { transfer from } \\
\text { 01/01/2019 }\end{array}$}} & \multirow[b]{3}{*}{$\begin{array}{c}\text { Estimated } \\
\text { commissio } \\
\text { n rate, \%* }\end{array}$} & \multirow[b]{3}{*}{$\begin{array}{l}\text { Commission } \\
\text { and Fee } \\
\text { revenue, } \\
\text { billion } \\
\text { roubles }\end{array}$} & \multicolumn{12}{|c|}{$\begin{array}{l}\text { Sensitivity investigation of the decline in commission revenue of credit institutions } \\
\text { as a consequence of a reduction in the "Cash Transfer" sign through: }\end{array}$} \\
\hline & & & & \multicolumn{3}{|c|}{$\begin{array}{c}\text { First Scenario: } \\
10 \% \\
\end{array}$} & \multicolumn{3}{|c|}{$\begin{array}{c}\text { Second } \\
\text { Scenario: } 20 \% \\
\end{array}$} & \multicolumn{3}{|c|}{$\begin{array}{c}\text { Third Scenario: } \\
30 \% \\
\end{array}$} & \multicolumn{3}{|c|}{$\begin{array}{l}\text { Fourth Scenario: } \\
50 \% \\
\end{array}$} \\
\hline & & & & 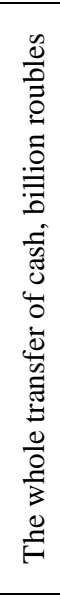 & 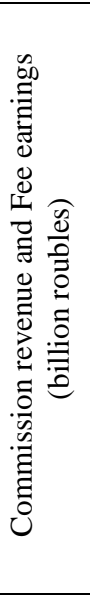 & 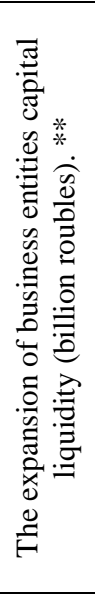 & 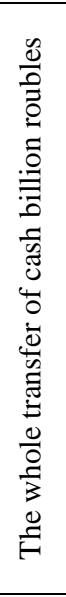 & 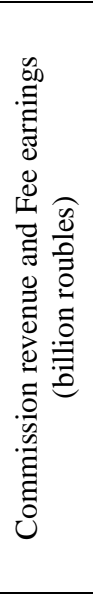 & 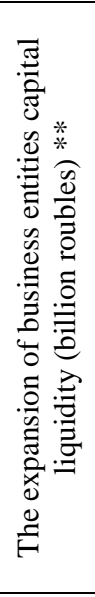 & 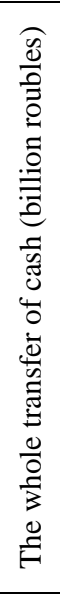 & 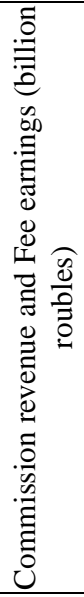 & 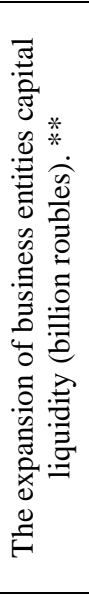 & 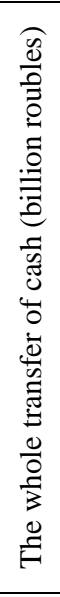 & 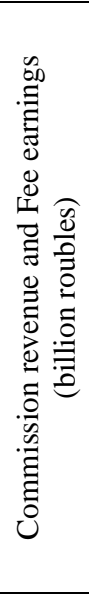 & 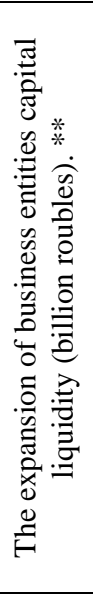 \\
\hline 1 & 2 & 3 & 4 & 5 & 6 & 7 & 8 & 9 & 10 & 11 & 12 & 13 & 14 & 15 & 16 \\
\hline $\begin{array}{l}\text { the } \\
\text { amount, } \\
\text { million } \\
\text { units }\end{array}$ & $\begin{array}{l}\text { volume } \\
\text {, billion } \\
\text { roubles }\end{array}$ & & & & & & & & & & & & & & \\
\hline$\frac{i}{2}$ & 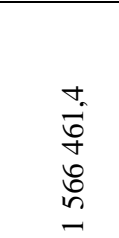 & 0,09 & 1396,8 & 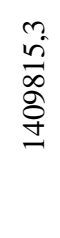 & 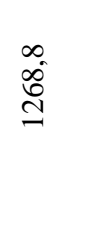 & $\begin{array}{l}0 \\
\stackrel{\infty}{\infty} \\
\stackrel{0}{\sim}\end{array}$ & 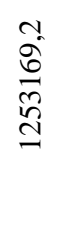 & ลे & $\begin{array}{l}\hat{\sigma} \\
\text { ôे } \\
\text { ते }\end{array}$ & 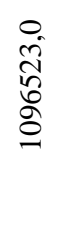 & 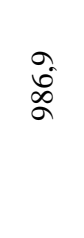 & बें & $\begin{array}{l}\hat{0} \\
\tilde{n} \\
\tilde{D} \\
\infty\end{array}$ & 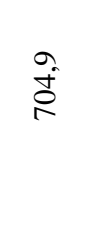 & के \\
\hline
\end{tabular}

* The rate value is defined through an estimation on the basis of the commission revenue ratio of credit institutions as well as the money transfers volume for the year

** The capital availability extension rate of economic entities matches to a decline in commission revenue of credit organizations (For First scenario, group four - group six)

\section{Results and Discussion}

Considering the outcomes of the evaluations, it can be concluded the extension potential for capital availability of business entities in the state economy as a consequence of the payment system transition to crypto transactions begins from 128 (first scenario) to 691.90 (forth scenario) billion roubles up to the range of the funds' transfer to the blockchain system.

Considering the low portion of the revenue of credit organizations made from commission revenue (approximately 1.0\%), it is notable to say that the decline in revenue following this matter is not that substantial for credit organizations in the Russian economy's financial sector.

Moreover, the expansion of business entities capitalization may well be of vital significance immediately for the national economy as well as business entities overall. 
Counting on the recommended research algorithm, and the dependencies acquired among the extent of transformations in modern assets and the GDP dynamics (Equation 1), table 2 displays the predicted prognostic estimations to the transition outcome of financial transactions to the blockchain on the dynamics of revenue as:

$$
Y=20513,2+0,79 x
$$

Table 2. Scenario prediction of GDP extension for the Russian Federation following the level of financial transaction systems into the blockchain

\begin{tabular}{lcccc}
\hline & First Scenario & Second Scenario & Third Scenario & Fourth Scenario \\
\hline GDP growth, (in \%) & $0,70 \%$ & $2,30 \%$ & $3,90 \%$ & $7,90 \%$ \\
\hline
\end{tabular}

The shown estimations express relatively average effects of the stages understudy on the economic growth dynamic, particularly based on scenario 1 . Simultaneously, it is necessary to stress that while the volume of crypto transactions rises, this impact grows apparent further.

Further, corresponding scenario assessments were implemented when realizing the second stage of the study focused on analyzing the effect of blockchain technologies on the system of operational processes of financial market organizations.

Next, relying on the above effects, a formalized assessment was made. It was accepted as the main hypothesis of this stage of the study that the introduction of blockchain technologies in the operational activities of the banking sector of the economy will minimize/eliminate operational and credit risks.

Tables 3 and 4 present scenario calculations that determine the possible effects generated as a result of a decrease in risks in the banking sector of the Russian economy and, accordingly, a decrease in the size of capital requirements for banks in relation to operational and credit risk (Table 3, 4). It should be noted that scenario-based risk reduction models are in many respects consistent with the estimates of the consulting company AccentureConsulting [10].

Table 3. Scenario parameters for the operating risk capital coefficient, in \% of the average bank (financial institution) gross income for the last three years

The coefficient value reflecting the average level of unforeseen losses due to operational risk in relation to the amount of income received

\begin{tabular}{|c|c|c|c|c|c|c|}
\hline & \multicolumn{6}{|c|}{$\begin{array}{c}\text { The coefficient value reflecting the average level of unforeseen losses due to operational risk in } \\
\text { relation to the amount of income received }\end{array}$} \\
\hline & \multicolumn{4}{|c|}{ ScenarioParameters } & \multicolumn{2}{|c|}{ ActualParameters } \\
\hline & $\therefore$ ○ & 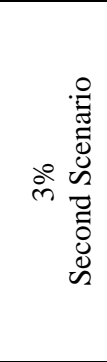 & 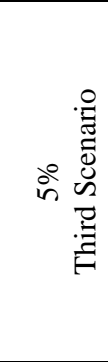 & 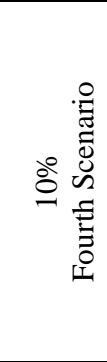 & $\begin{array}{c}\text { The value of } \\
\text { operational risk (OR) } \\
\text { with a coefficient of } \\
12.5 \text { in accordance } \\
\text { with the instruction of } \\
\text { the Central Bank of } \\
\text { the Russian } \\
\text { Federation. } \\
\text { As of } 01.01 .2020 \\
{[11] .}\end{array}$ & $\begin{array}{l}15.0 \% \text { (in } \\
\text { accordance with the } \\
\text { operational risk } \\
\text { assessment } \\
\text { methodology set out } \\
\text { in the Basel } \\
\text { Committee capital } \\
\text { adequacy agreement } \\
\text { "Basel II"). }\end{array}$ \\
\hline $\begin{array}{l}\text { Amount of capital } \\
\text { requirements in } \\
\text { relation to operational } \\
\text { risk, billion roubles }\end{array}$ & 651,0 & 1953,0 & 3255,0 & 6509,9 & 8137,4 & 9764,9 \\
\hline
\end{tabular}


Table 4. Scenario parameters for the credit risks capital (calculated based on the Regulation of [11; 12], in\%

\begin{tabular}{cccc}
\hline & 01.01 .2017 & 01.01 .2018 & 01.01 .2019 \\
\hline Scenario 1 & 173,3 & 187,9 & 214,7 \\
\hline Scenario 2 & 3118,5 & 3654,5 & 4134,7 \\
\hline Scenario 3 & 3869,1 & 4438,9 & 4923,6 \\
\hline Scenario 4 & 4244,4 & 4831,0 & 5318,1 \\
\hline
\end{tabular}

In relation to scenario modelling of credit risks, scenarios include:

1. Scenario 1 is an idealized model, according to which loans of such categories as doubtful, non-performing and uncollectible are eliminated as part of the systems penetration concept into the financial environment.

2. Scenario 2 provides for the "calibration" of decisions of a credit institution on the feasibility of including counterparty in the bank's circle of customers based on its reputation in an open blockchain system.

3. Scenario 3 is based on Scenario 2, considering the fact that the use of blockchain technologies in the financial system will reduce doubtful and non-performing loans by $50 \%$.

4. Scenario 4 is based on Scenario 2, considering the fact that the use of blockchain technologies in the financial system will reduce doubtful and non-performing loans by $25 \%$.

Given that bank reserves, in fact, "mothball" the liquidity of financial credit institutions, their creation generates the prerequisites for reducing the financial results of the banking sector of the economy. Undoubtedly, the formation of reserves is one of the mechanisms of the central regulator that contributes to the sustainable development of the financial sector of the economy in the context of its possible turbulence caused, for example, by the growth of overdue debts in the loan portfolio. Without going into details about the reservation rates established by the Central Bank of the Russian Federation for one or another risk of the banking sector, it is unambiguously necessary to state that financial institutions suffer losses as a result of reduced liquidity as part of the "freezing" of assets in reserved funds.

In order to detect such dependencies, models have been built that evaluate the result of operational and credit hazards on critical parameters of the financial results of the banking area (equation 1 and equation 2 - Models of the effect of credit and operational hazards on the financial results of credit organizations, respectively).

Where:

$$
\begin{aligned}
& Y=12,240+0,19 \mathrm{X}_{1}-0,180 \mathrm{X}_{2} \\
& Y=-437,280+0,23 \mathrm{X}_{1}-0,3 \mathrm{X}_{3}
\end{aligned}
$$

$\mathrm{Y}$ - Financial performance of credit institutions, billion roubles

$\mathrm{X} 1$ - The volume of loans issued billion roubles.

$\mathrm{X} 2$ - The value of operational risk (OR) with a coefficient of $12.5 \%$, billion roubles.

X3 - The reserve created for possible losses on loans.

The reliability of the obtained models is determined by the correspondence of the essential factors to their normative values.

The results obtained predictably demonstrate a very significant effect of the growth of operational and credit risk reserves on the volume and dynamics of credit organizations financial results.

Returning to the previously constructed regression models that assess the relationship between the financial results of the banking sector and the level of reserved capital for credit and operational risks, Table 5. shows the calculations of the change in the indicator characterizing the financial results of the banking sector in accordance with the developed baseline scenario based on minimalistic estimates of the decrease in reserves. 
Table 5. The effect evaluation of credit and operational risks on changes in the profits of the economy banking sector (basic scenario 4 providing for the minimum possible effects generated by the penetration of blockchain inside the operational activities), billion roubles

\begin{tabular}{ccc}
\hline $\begin{array}{c}\text { The value of operational } \\
\text { risk (Fact/baseline) }\end{array}$ & $\begin{array}{c}\text { Credit Risk Value } \\
\text { (Fact/Baseline) }\end{array}$ & $\begin{array}{c}\text { The increase in financial results of the banking sector } \\
\text { as a result of the decline: } \\
\text { operational risk/credit risk/total }\end{array}$ \\
\hline $8137,4 / 6509,9$ & $5712,6 / 5318,1$ & $+58,6 /+29,9 /+88,5$ \\
\hline
\end{tabular}

\section{Summary}

The implemented calculations built within the framework of using the scenario modelling concept, demonstrate very impressive parameters for the growth of the banking sector's financial results in the process of using blockchain technologies in operational activities. In accordance with the estimates obtained, the introduction of distributed data storage technologies in the operational activities of credit institutions is able to provide an increase in financial results up to 88.5 billion roubles (which is about $4.5 \%$ of the actual value of the indicator as of 01.01. 2020) within the framework of the baseline scenario.

An assessment of the possible consequences of the blockchain technology penetration into the banking environment creates the potential for a formalized assessment of changes that may occur in the national economic system as a whole. This, in turn, allows us to move on to developing new models of economic growth under the influence of the digitalization elements of the economy (in particular, as a result of the blockchain technologies usage in the financial sector).

In accordance with the assessments implemented and relying on the previously proposed organizational chart to investigate the significance of blockchain technologies to the development items of the national economy, a model has been developed that assesses the relationship between the financial results level of credit institutions and the GDP dynamics (equation 3).

$$
Y=28846,7+45,8 x_{1}
$$

In accordance with the obtained model, prognostic scenario estimates of Russia's GDP growth were determined in penetration case of the distributed data storage technologies into the system of operational processes of credit organizations (in accordance with the basic scenario assuming the least possible effects) (Table 6).

Table 6. Scenario prediction of the GDP extension in the Russian Federation based on the transition range of the financial transaction system to the blockchain system

The value of the increase in financial results of credit organizations (baseline scenario 4)

Estimation of GDP growth

$+88,5+14,6 \%$

Furthermore, it is noteworthy that the functional effects of blockchain on the development efficiency of the national economic system are undoubtedly not limited to the effects considered here. The technologies under consideration also have a significant impact on the liquidity risk of credit institutions because of minimizing their reserved capital. No less significant effects are generated within the framework of the asset and liability management system, in the field of supporting business decisions, regulating relations with contractors, etc [10].

\section{Conclusions}

This survey examines the national economy below the impact of blockchain technology. 
To that end, methodological methods have been considered.

In conclusion, we would like to note that blockchain technologies can significantly transform existing business processes in the same way that digitalization of the socioeconomic environment destroys traditional areas of economic activity (for example, digital channels have replaced analogue ones). This also includes the financial sector; thereby the blockchain technologies would continue to develop the FinTech paradigm.

In this regard, given the very high rate of penetration of blockchain technologies in the economy's real-sector, as well as in the view field of the expert and scientific community, it becomes extremely important to overcome the vacuum in understanding the essence and importance of distributed storage technologies until they become a reality and finally penetrate in the sphere of business processes of business entities.

\section{Acknowledgements}

The research was conducted by permission from the Foundation of Russian Science (project Number 19-18-00202)

\section{REFERENCES}

[1] Alibaba, Baidu and four state-owned banks of China are developing blockchain applications. RBC. [Electronic source]. - Access mode: https://www.rbc.ru/crypto/news/5ea084669a79473778999010, free access (29.04.2020)

[2] Blockchain in banking: analysis of the value of technology for investment banks [Electronic source]. Access mode: https://habr.com/en/company/wirex/blog/400565/, free access (22/04/2020).

[3] Coindesk. (2017a). Blockchain Q1 Report. Retrieved from http://www.coindesk.com/coindesk-releasesstate-of-blockchain-q1-2017-research-report/

[4] Guo, Ye., \& Chen, L. (2016). Blockchain application and outlook in the banking industry. Financial Innovation 2(1), p. 24.

[5] IBM. n.d. IBM Blockchain. Retrieved from https://www.ibm.com/blockchain/what-is blockchain.html

[6] Ngai, J.L. (2016). Blockchain - Disrupting the Rules of the Banking Industry [J]. Report by McKinsey 5.

[7] Rechtman, Y. (2017). Blockchain: The Making of a Simple, Secure Recording Concept. The CPA Journal 87(6), pp. 15-17.

[8] Report "Overview: the banking sector in 2019" [Electronic source]. - Access mode: https://cbr.ru/Collection/Collection/File/19777/obs_200.pdf, free access (04/22/2020)

[9] Safiullin, M., Abdukaeva, A., \& Yelshin, L.A. (2019). Integrated multicomponent assessment of the blockchain technology market development in national economy of Russia. Innovation 7(249), pp. 4149.

[10] Statistics of the national payment system [Electronic source]. - Access mode: https://cbr.ru/statistics/nps/psrf/, free access (14.04.2020)

[11] The Bank of Russia Regulation dated June 28, 2017 No. 590-P "On the Procedure for Forming Credit Provisions by Credit Institutions for Possible Losses on Loans, and also Loan and Equivalent Debts" https://www.garant.ru/products/ipo/prime/doc/71621612/

[12] The launch date for the national cryptocurrency of China has become known. RBC, 04.16.2020. [Electronic source]. - Access mode: https://www.rbc.ru/crypto/news/5e982b909a7947cba287a41b, free access (29.04.2020)

[13] Tilooby, et al., (2018). The Impact of Blockchain Technology on Financial Transactions. Dissertation, Georgia State University.

\section{Article history:}

Received 18 September 2020

Accepted 28 November 2020 